\title{
Preservation of latest Cretaceous (Maastrichtian)-Paleocene frogs (Eorubeta nevadensis) of the Sheep Pass Formation of east-central Nevada and implications for paleogeography of the Nevadaplano
}

\author{
Joshua W Bonde ${ }^{\text {Corresp., } 1}$, Peter A Druschke ${ }^{2}$, Richard P Hilton ${ }^{3}$, Amy C Henrici ${ }^{4}$, Stephen M Rowland ${ }^{5}$ \\ 1 Department of Conservation and Research, Las Vegas Natural History Museum, Las Vegas, Nevada, United States of America \\ 2 ExxonMobil Upstream Oil and Gas, Houston, Texas, United States of America \\ 3 Natural History Museum, Sierra College, Rocklin, California, United States of America \\ ${ }^{4}$ Section of Vertebrate Paleontology, Carnegie Museum of Natural History, Pittsburgh, Pennsylvania, United States of America \\ 5 Department of Geoscience, University of Nevada - Las Vegas, Las Vegas, Nevada, United States \\ Corresponding Author: Joshua W Bonde \\ Email address: paleo@lvnhm.org
}

Here we report on exceptional preservation of remains of the frog Eorubeta nevadensis in deposits of the Sheep Pass Formation, ranging from Late Cretaceous to Eocene, in the south Egan Range, Nevada. This formation represents a lacustrine basin within the Sevier retroarc hinterland. The formation is subdivided into six members $(A-F)$; of interest here are members $B$ and $C$. The base of member $B$ is ? uppermost Cretaceous-Paleocene, while member $C$ is Paleocene. Member $B$ frogs are preserved in three taphonomic modes. Mode 1 frogs are nearly complete and accumulated under attritional processes, with frogs settling on microbial mats, as evidenced by crenulated fabric of entombing limestone. Mode 2 involves accumulation of frogs as a result of attritional processes. These frogs are mostly complete with some showing evidence of invertebrate scavenging. Possible scavengers are gastropods, ostracods, and decapods. Mode 3 is represented by isolated, reworked remains of frogs as a result of storm activity, supported by the association of elements with disarticulated bivalves and mud rip-up clasts. Member $\mathrm{C}$ preserves frogs in two taphonomic modes. Mode 4 are nearly complete frogs that accumulated during discrete mass mortality events. Numerous individuals are preserved along bedding planes in identical preservational states. Mode 5 is beds of frog bone hash, which represent increased energy to the depositional system (likely tempestites) and reworking of previously buried frog remains. Taphonomy of the frogs, along with the associated fauna and flora, are consistent with preservation in a cool, temperate lake basin, supporting previous interpretations that the Nevadaplano was an elevated plateau during the late Cretaceous through the Eocene. This is a period of time coincident with a climatic thermal 
optimum, thus the most parsimonious explanation for a temperate lake at the latitude of east-central Nevada is to invoke high elevation, which is consistent with independent structural and clumped stable isotope studies. 
1

2

3

4

5

6

7

8

24

25

26

27

28

29

30

31

32

33

34

35

36

37

38

39

Joshua W. Bonde ${ }^{1}$, Peter A. Druschke², Richard P. Hilton ${ }^{3}$, Amy C. Henrici ${ }^{4}$, Stephen M.

Rowland ${ }^{5}$

${ }^{1}$ Department of Conservation and Research, Las Vegas Natural History Museum, Las Vegas, Nevada, United States of America

${ }^{2}$ ExxonMobil Upstream Oil and Gas, Houston, Texas, United States of America

${ }^{3}$ Natural History Museum, Sierra College, Rocklin, California, United States of America

${ }^{4}$ Section of Vertebrate Paleontology, Carnegie Museum of Natural History, Pittsburgh, PA, USA

${ }^{5}$ Department of Geoscience, University of Nevada-Las Vegas, Las Vegas, Nevada, United States of America

Corresponding Author:

Joshua Bonde ${ }^{1}$

Las Vegas Natural History Museum, 900 Las Vegas Blvd. North, Las Vegas, NV 89101

Email address: paleo@lvnhm.org 


\section{Abstract}

41 Here we report on exceptional preservation of remains of the frog Eorubeta nevadensis in

42 deposits of the Sheep Pass Formation, ranging from Late Cretaceous to Eocene, in the south

43 Egan Range, Nevada. This formation represents a lacustrine basin within the Sevier retroarc

44 hinterland. The formation is subdivided into six members (A-F); of interest here are members B

45 and C. The base of member B is ?uppermost Cretaceous-Paleocene, while member C is

46 Paleocene. Member B frogs are preserved in three taphonomic modes. Mode 1 frogs are nearly

47 complete and accumulated under attritional processes, with frogs settling on microbial mats, as

48 evidenced by crenulated fabric of entombing limestone. Mode 2 involves accumulation of frogs

49 as a result of attritional processes. These frogs are mostly complete with some showing evidence

50 of invertebrate scavenging. Possible scavengers are gastropods, ostracods, and decapods. Mode 3

51 is represented by isolated, reworked remains of frogs as a result of storm activity, supported by

52 the association of elements with disarticulated bivalves and mud rip-up clasts. Member C

53 preserves frogs in two taphonomic modes. Mode 4 are nearly complete frogs that accumulated

54 during discrete mass mortality events. Numerous individuals are preserved along bedding planes

55 in identical preservational states. Mode 5 is beds of frog bone hash, which represent increased

56 energy to the depositional system (likely tempestites) and reworking of previously buried frog

57 remains. Taphonomy of the frogs, along with the associated fauna and flora, are consistent with

58 preservation in a cool, temperate lake basin, supporting previous interpretations that the

59 Nevadaplano was an elevated plateau during the late Cretaceous through the Eocene. This is a

60 period of time coincident with a climatic thermal optimum, thus the most parsimonious

61 explanation for a temperate lake at the latitude of east-central Nevada is to invoke high elevation,

62 which is consistent with independent structural and clumped stable isotope studies.

\section{Introduction}



system of the western United States have yielded a wealth of fossil plant, invertebrate and vertebrate remains, however comparatively few paleontological studies exist for coeval

67 intermontane deposits of the Sevier retroarc hinterland region. The Upper Cretaceous-Eocene

68 Sheep Pass Formation of east-central Nevada represents deposits of a synconvergent extensional

basin within the Sevier retroarc hinterland (Druschke et al., 2009a,b; 2011). It occupied what is widely interpreted as a high-elevation orogenic plateau (Coney and Harms, 1984; Jones et al., 1998; Dilek and Moores, 1999; DeCelles, 2004; Snell et al., 2014). Previous studies of the Sheep Pass Formation type section have focused on palynology (Fouch, 1979) and invertebrates such as mollusks (Good, 1987) and ostracodes (Swain, 1987). Remarkably, the only fossil vertebrate that is known from the $>1 \mathrm{~km}$ thick Sheep Pass Formation type section are the fossil frogs discussed herein, wihc recently were identified (Henrici et al., 2018) as Eorubeta nevadensis.Ancient highelevation sedimentary packages are rarely preserved in the stratigraphic record due to intense erosional processes at high elevations over extended periods of time. In addition to the processes of erosion, the Sevier hinterland has been subjected to several episodes of Paleogene and Neogene extension and volcanism that have further disrupted the original continuity of synorogenic deposits of the Sheep Pass Formation (Druschke et al., 2009a,b; 2011). Given the rarity of ancient high-elevation sedimentary deposits, it is even rarer to find records of ancient high-elevation biotas. Thus the Sheep Pass Formation provides a unique opportunity to investigate the preservation of biological remains in a high-elevation setting.

$$
\text { During the course of this study, we have recovered dozens of partial to nearly complete }
$$
fossil frog specimens (34 frogs from Member B and 45 from Member C, not counting those that are fragmentary) from the Sheep Pass Formation type section, many of which are mostly 
87 complete, as well as a number of laterally extensive frog bonebeds. Exceptional preservation in

88 this case refers to common preservation of nearly complete individuals as well as the abundance

89 of elements; no soft tissue preservation has been found as yet. Frogs are the only vertebrates

90 identified within the Sheep Pass Formation type section to date (except for one fragmentary

91 mandible which may be a mammal as well as several other as yet unidentified large isolated

92 fragmentary bones). We have also documented potential decapods, trace fossils, and scattered 93 plant remains, in association with previously documented ostracod and mollusk faunas. These

94 discoveries present an interesting pattern of community structure and preservation within the

95 Sevier hinterland during the latest Cretaceous and Paleogene. In this paper we describe the 96 taphonomic parameters of fossil material collected from the Sheep Pass Formation type section 97 and interpret the preservational modes of the fossils. We also consider what this fossil material 98 may reveal about the ecology and evolution of this long-lived, high-altitude lake basin.

The Sevier orogen is typified by thin-skinned thrust faulting and resultant crustal thickening in the Sierra Nevada retroarc region, resulting from prolonged Jurassic to Paleogene 102 eastward subduction of the oceanic Farallon plate beneath the western margin of North America 103 (DeCelles, 2004, and references therein). Following maximum crustal thickening in the Late 104 Cretaceous, east-central Nevada is generally envisioned as part of a high-elevation orogenic 105 plateau (Coney and Harms, 1984; Jones et al., 1998; Dilek and Moores, 1999; DeCelles, 2004).

106 Synconvergent, surface-breaking normal faults documented within the Sheep Pass Formation 107 suggest that syncontractional extension had initiated by latest Cretaceous time in the Sevier 108 hinterland of east-central Nevada, resulting in a series of basins generally analogous to the high109 elevation graben systems of the modern Puna-Altiplano and Tibetan Plateau (Druschke, 2008; 
110 Druschke et al., 2009a,b). In support of a high-elevation interpretation, clumped stable-isotope

111 analyses of lacustrine carbonates within the basal Sheep Pass Formation suggest a 2.2 to $3.1 \mathrm{~km}$

112 paleoelevation for east-central Nevada during the latest Cretaceous and earliest Paleocene, some

$1132.2 \mathrm{~km}$ higher than the foreland basin in Utah at that time (Snell et al., 2014). The Sevier

114 hinterland was subsequently affected by a southward younging sweep of middle to late Eocene

115 extension and associated volcanism (Armstrong and Ward, 1991; Gans et al., 2001) that

116 reactivated elements of the Sheep Pass basin system (Druschke et al., 2009a). Most recently,

117 large-magnitude Neogene Basin and Range extension subjected the Sheep Pass Formation to

118 differential uplift, erosion, and burial beneath younger extensional basins.

119 The Sheep Pass Formation, first described by Winfrey $(1958,1960)$, is a sedimentary

120 package that forms isolated outcrops in various mountain ranges of east-central Nevada (Fig. 1).

121 The Sheep Pass Formation is divided into members A-F based largely upon lithology (Fig. 2).

122 Previous workers have determined that the primary depositional settings of the Sheep Pass

123 Formation are lacustrine, alluvial fan, and fluvial (Winfrey, 1958, 1960; Kellogg, 1964; Fouch,

124 1979; Druschke, 2008).

125 Whereas the current study documents the first identifiable vertebrate remains from the 126 type section, previous studies have recorded vertebrate remains from other localities within the

127 Sheep Pass Formation. Fouch (1979) identified the remains of the insectivore-like mammal

128 Nyctitherium within Paleocene to Eocene lacustrine carbonates of the Grant Range (Fig. 1).

129 Emry (1990) identified a mammalian fossil assemblage, including also anurans, lizards, and 130 snakes of Eocene (Bridgerian) age at the northern Egan Range, Elderberry Canyon location. Of 131 most direct relevance to the current study, Hecht (1960) identified the remains of two fossil frogs 132 recovered from a petroleum exploratory drill core located just west of the Sheep Pass Formation 
133 type section in White River Valley. These specimens, which he assigned to a new genus and

134 species, Eorubeta nevadensis, were recovered from a lacustrine limestone correlative to Member

135 B or C. Hecht (1960) noted that frog population densities would have to be very high to preserve

136 the two specimens found within a single core, although it would take nearly fifty years for

137 specimens to be found in natural outcrops within the Sheep Pass Formation type section.

138 Absolute age control places the maximum depositional age of the basal Member A at

$13981.3 \pm 3.7 \mathrm{Ma}$ based upon (U-Th)/He cooling ages of detrital zircons, with the upper portion of

140 Member A also yielding two euhedral detrital zircons with respective U-Pb ages of 68 and $70 \pm$

141 1Ma (Druschke et al., 2009b). The basal part of Member B in the type-area is $66.1 \pm 5.1 \mathrm{Ma}$

142 based upon $\mathrm{U} / \mathrm{Pb}$ dating of biogenic carbonates (Druschke et al., 2009b). The rest of Members B

143 and $\mathrm{C}$ is constrained as Paleogene based upon biostratigraphy (Fouch, 1979; Good, 1987, Henrici

144 et al., 2018). Taking into account the inherent uncertainties in previous absolute and

145 biostratigraphic age control, the K-Pg boundary may be present in the Sheep Pass Type Section,

146 but to date this has not been identified.

\section{Materials \& Methods}

148

149

150

151

152

153

154

155

156

157
Prospecting and Surface Collection

Fossil localities were discovered by prospecting exposures of the Sheep Pass Formation

type section within the Sheep Pass Canyon area. The positions of fossil sites, including isolated elements, were plotted on a topographic map, their GPS coordinates recorded (these coordinates are on file at the respective repositories of the specimens), then specimens were taphonomically assessed before being collected (those reposited at Sierra College Natural History Museum and Las Vegas Natural History Museum) or later in the laboratory (those reposited at Carnegie Museum of Natural History).

Sedimentological data were recorded at each fossil locality to determine their

Peer) reviewing PDF | (2020:01:44927:1:2:NEW 4 May 2020) 
158 depositional environments. Only surface collections were made; no excavations were conducted.

159 Fossil material was noted as float or as in situ. In situ material was discovered by splitting the

160 exposed mudstones with a rock hammer. Collected specimens are reposited at:

161 Sierra College Natural History Museum, Rocklin, CA (SCNHM)

162 Carnegie Museum of Natural History, Pittsburgh, PA (CM)

163 Las Vegas Natural History Museum, Las Vegas, NV (LVNHM)

164 (all figured specimens in this paper are housed at the SCNHM or the CM)

165 Each fossil locality was placed within the stratigraphic framework of Druschke (2008),

166 which allowed for identification of fossiliferous members of the Sheep Pass Formation. All

167 fossils so far discovered are from Member B (? Upper Cretaceous-Paleocene) and Member C

168 (Paleocene). Locality data are reposited with specimens at their respective institutions. All field

169 work was conducted under permit from the Bureau of Land Management (8270(NV040) 2009 to

$170 \mathrm{RPH})$.

171

Taphonomic Analysis

172

Taphonomic observations recorded included spatial distributions of specimens, degree of

173 articulation and/or close association of disarticulated elements, presence of bone-on-bone

174 contacts, types of bone breakages, and alteration halos. These taphonomic modifiers were

175 revisited in the lab as well, and under light microscope. We obtained data on surface

176 modification in the lab, after preparation of elements, because such features are often obscured

177 by matrix (Eberth et al., 2007). Surface modification data include weathering (after

178 Behrensmeyer, 1978), abrasion (after Shipman, 1981), tooth marks, bioerosion, trample marks,

179 and the nature of breaks (e.g., faults, blocky, spiral). Trend and plunge data of long-bone

180 elements were measured to determine whether elements have been aligned due to fluid flow, or

181 whether the bones are oriented randomly.

Peer] reviewing PDF | (2020:01:44927:1:2:NEW 4 May 2020) 


\section{Member B Paleontology \& Taphonomy}

183

184

185

186

187

188

189

190

191

192

193

194

195

196

197

198

199

200

201

202

203

204

Member B of the Sheep Pass Formation type section has produced a diverse assemblage

of plants, invertebrates, and vertebrates. Ostracods are the most numerous invertebrates, and

frogs are the only vertebrates recovered to date, with the exception of a mammal jaw with teeth not preserved. In addition to body fossils, there are also some invertebrate traces preserved

within Member B. Plant body fossils are present in isolated horizons throughout Member B.

Fossils are found in at least three different lithofacies: dolomitic clayshales, dolomitic microbialites, and tempestites.

Plants

There are at least four types of plant body impressions. The first type consists of portions or bracts of a larger organ that is $1 \mathrm{~cm}$ long and up to $1.5 \mathrm{~mm}$ in diameter. Perpendicular to the long axis are shorter appendages. The second type consists of long (up to $20 \mathrm{~cm}$ ), 2-3 cm wide impressions, with parallel structures along the long axis. These impressions maintain their width from the base until they finally taper to a tip at their distal end (Fig. 3). These are the best preserved plant specimens. Both types of plant fossils are found in a very fine dolomitic clayshale, which contains only plant fossils; no animal body or trace fossils are present. The third type is a single, unidentified, angiosperm leaf, roughly $5-6 \mathrm{~cm}$ from petiole to the tip of the leaf (Fig. 4). A dominant primary vein extends from the petiole to the tip of the leaf, with arcuate secondary veins occurring on opposite sides of the primary vein. The margin of this leaf is entire and is eucamptodromous in morphology (Fig. 4) (cf. Hickey, 1973). This specimen was found in an irregularly laminated, dolomitic mudstone. The forth type is a partial gymnosperm leaf. It is 2-3 cm wide, with the distal portion not preserved. The venation is dichotomous, with an entire margin and acute base, consistent with a ginkgophyte (Tidwell, 1998). 
206 level was low enough for these plants to subsist in this portion of the basin. Lower and higher in

207 the stratigraphic section the water was probably too deep for such plants. This interpretation is

208 supported by the absence of fossil gymnosperms higher or lower in the section. Allochthonous

209 macrofloral material in lakes rarely travels farther than 50 meters from the source plant

210 (Ferguson, 1985); thus we interpret the shore of the paleolake to likely have been within $50 \mathrm{~m}$ of

211 the sites where these fossils were deposited.

212 The scarcity of plant fossils does not allow for a more comprehensive picture of the plant

213 life within the basin in which the Sheep Pass Formation type-section was deposited. Little can be

214 said about the plant record, as to what the surrounding foliage was like, nor can these fossils lend

215 themselves to rigorous paleoclimatic analysis. The previous palynological study by Fouch (1979)

216 found mostly charophytes and algae.

217

218

219

220

221

222

223

224

225

226

227

Invertebrates

Numerous invertebrate fossils occur in Member B, including body fossils of mollusks and crustaceans. Bivalves, typically less than a centimeter in diameter, are found isolated in planar-laminated, dolomitic mudrock lithofacies, or they occur concentrated in irregularly bedded dolomitic mudstone, along with fine-grained mudstone intraclasts. Ostracods are extremely abundant in planar laminated, dolomitic mudrock lithofacies. In some of these beds ostracods are the only fossils preserved in abundance, whereas in other beds they occur in close association with vertebrate remains. Ostracods present in this unit are Clinocypris? sp., Paracypridopsis? sp., and Cypridea bicostata (Swain, 1987).

Occasional impressions of potential decapod carapaces are found within the dolomitic mudstone lithofacies, in both the planar-laminated and crenulated fabric beds. The impressions 
228 are typically partitioned into $4-5$ segments (Fig. 5). These attached segments are all slightly

229 concave, in which each segment is nearly a centimeter in width and a few millimeters in length.

230 The specimen shown in Fig. 5 is articulated with a more massive structure divided along a

231 midline and oriented at $90^{\circ}$ to the former structure. We interpret these structures to be articulated

232 abdominal somites, part of the telson and posterior, dorsal parts of the cephalothorax of a

233 potential decapod (similar to Fetzner, 2002).

234 Invertebrate remains and traces in Member B are typically found in a single lithofacies,

235 the planar-laminated, dolomitic limestone. Ostracods tend to be concentrated, with dozens of

236 individuals in a small area (less than a meter square). Previous workers concluded that ostracods

237 (Swain, 1987) and mollusks (Good, 1987) from Member B are indicative of an alkaline, open-

238 lake environment. In some instances the ostracods are found in direct contact with vertebrate

239 bones (Fig. 6). The densest accumulations of ostracods are found in and around the cranium and

240 other bone elements of frog fossils. This suggests that either the ostracods accumulated after the

241 soft tissue of the frog was already decomposed or, perhaps, that the ostracods swarmed the frog

242 carcass to scavenge the carrion. Ostracod swarming is a diagnostic sign of scavenging in both the

243 fossil and modern records (Wilkinson et al., 2007). In addition to being found in close

244 association with vertebrate remains, ostracods are found scattered along bedding planes of the

245 planar-laminated limestones.Another occurrence of ostracods in Member B is along the

246 agglutinated edges and meniscate infilling laminae of vertical decapod burrows. These

247 specimens may either be accumulations of ostracods at normal background rates, or they may be

248 the remains of individuals preyed upon or scavenged by decapods. A study by Gutierrez-Yurrita

249 et al. (1998) of crayfish gut contents showed that ostracods account for about $10 \%$ of crayfish

250 diet. Ostracods are not found in any other lithofacies in Member B. 

bivalves. Good (1987) identified this mollusk assemblage as a Valvata, Hydrobia-Sphaeriidae association; along with the ostracod assemblage, these mollusk taxa support the interpretation of

254 255

an open, alkaline-lacustrine setting (Good, 1987). Analogous modern mollusk assemblages occur in temperate lakes of North America, in Ontario, Minnesota, and Maine (Good, 1987).

Bivalves are preserved in two taphonomic modes. The less common mode of preservation is as isolated, articulated specimens in planar-laminated, dolomitic limestone. These specimens are interpreted to be the result of attritional accumulation over time. The second, and more common, preservational mode is articulated and disarticulated valves found amongst irregular clasts of underlying clayshale strata in an otherwise silty, irregularly-bedded, dolomitic limestone. We interpret this preservational style to represent tempestite beds, with mudrock clasts being mud rip-up clasts. That, coupled with the dense accumulation of articulated and disarticulated specimens, suggests that at least some of the valves were remobilized. The irregular bedding, disarticulated valves, and mud rip-up clasts indicate that these beds represent periods of increased wave energy in the system rather than fluvial influxes, because there are no signs of sedimentary structures indicative of fluvial processes, such as clast imbrications or cross-laminae.

\section{Vertebrates}

Numerous frog specimens have been recovered from Member B of the Sheep Pass Formation within the Sheep Pass type section. These specimens are found stratigraphically throughout this member (Fig. 2). All specimens are preserved within dolomitic mudstones, and most of them exhibit dorsoventral compression. 
274 individuals preserved as nearly complete skeletons only within those dolomitic mudstones with a 275 crenulated-fabric (i.e., SCNHM VAF 3, Fig. 7). The lack of evidence of exposure and transport 276 supports an interpretation that frogs in this taphonomic mode accumulated through attrition over 277 time. This interpretation is supported by the vertical and lateral stratigraphic distribution of 278 specimens that had settled onto microbial mats in life position and were subsequently buried and 279 preserved; there are no discrete event beds. Crenulated laminations are an artifact of microbial 280 mat sedimentation (James, 1977). Actualistic studies of fish carcasses reveal that water 281 temperatures must be below $15^{\circ} \mathrm{C}$ in order for a carcass to sink (Elder, 1985). In another 282 actualistic study Dodson (1973) showed that a frog bloated and floating in a tank will begin to 283 decompose and disarticulate after 21 days. In yet another actualistic experiment, frog carcasses 284 began to decompose and disarticulate in just a few days (Iniesto et al., 2017). Similarly, the 285 mostly complete frog specimens encountered in this study likely sank to the bottom within a few 286 days of death. The lack of scavenging could be attributed to periods of anoxic or dysoxic 287 conditions, as suggested by petroleum biomarkers from Sheep Pass Formation derived oil 288 (Ahdyar, 2011). However, the relative abundance of invertebrate trace fossils within these 289 crenulated fabric horizons suggests oxygen levels were not so low as to deter potential 290 invertebrate scavengers from feeding on the lake bottom. A potential mechanism to inhibit 291 scavenging in the presence of oxic waters is rapid carbonate precipitation mediated by the 292 microbial mats (after Dupraz et al., 2009). Modern rates of carbonate precipitation in microbial 293 settings can be as much as 100 microns per day (Lebron and Suarez, 1996). Rapid microbially 294 mediated carbonate precipitation could have quickly removed frog carcasses from being 295 accessible to invertebrate scavengers. Another mechanism which could have led to the intact 
296 preservation of frog carcasses is the initial entombment in a microbial mat sarcophagus (Iniesto 297 et al., 2017). Such sarcophagus settings have been shown in a lab to preserve articulated frogs 298 and soft tissue for up to three years (Iniesto et al., 2017), which could allow for sufficient time 299 for burial in a lacustrine setting. Taphonomic Mode 2 is similar to the first in that specimens are typically nearly

301 302 303 304 305 306 307 308 309

complete; the difference is that there are no signs of microbial mats, ais indicated by the lack of the crenulated fabric sedimentary structures. This mode is hosted in a planar-laminated, dolomitic limestone and, unlike the first vertebrate taphonomic mode, these are the horizons that contain abundant ostracods (cf. SCNHM VAF 26 A, Fig. 8). Many of the frogs preserved in this lithofacies are found in postures slightly more out of "life position" than those in the microbialites such as head to body angle or joint angles not in a relaxed living frog posture, suggesting that they may have been subjected to additional transport or scavenging. As mentioned above, some of these frogs appear to have been scavenged by ostracod swarming. Other specimens with elements displaced in random directions from the main part of the animal are consistent with invertebrate scavenging (Elder and Smith, 1984), although minor lacustrine currents could have similarly displaced small elements. The fact that these frogs are also almost complete supports the interpretation that they must have sunk within three weeks of death if not much sooner (Dodson, 1973; Iniesto et al., 2017). In order to sink without bloating and disarticulating, water temperature was likely below $15^{\circ} \mathrm{C}$ (Elder, 1985). In light of the stratigraphic distribution of this lithofacies, we interpret this taphonomic mode also to be attritional, with frogs dying and settling to the bottom through time.

The final taphonomic mode of frog elements in Member B, Taphonomic Mode 3, is related to the taphonomic mode described for bivalves in the beds interpreted as tempestite 
319 horizons. These frog elements are typically found isolated and associated with disarticulated

320 bivalve valves and mud rip-up clasts. The frog bones are interpreted as having been reworked

321 from either the lake bottom or underlying sediments. Dodson (1973) showed that even frog

322 bones that have been submerged for long periods of time can be easily transported.

323

324

325

326

327

328

330

331

332

333

334

335

336

337

338

339

340

341

\section{Trace Fossils}

There are numerous burrows preserved within the dolomitic mudrocks of Member B.

One type consists of randomly sinuous, continuous trails (Fig. 9), roughly $0.8-1.0 \mathrm{~cm}$ wide and U-shaped in cross section. These trails are observed only in irregularly laminated mudrocks with crenulated fabric. Another common burrow stands out in slight positive relief, $\sim 1 \mathrm{~cm}$, along bedding planes of relatively flat laminated mudrock. In plan view, these are nearly perfectly circular, with diameters ranging from $5-7 \mathrm{~cm}$, and they cut across stratigraphic layers to depths at least $6 \mathrm{~cm}$ deep. In the lab, we cut one of these burrows in half longitudinally to expose the internal structure (Fig. 10). Along the outer edge of the burrow, the mudrock becomes darker in color and is lined with occasional ostracods along the margins. In between the dark margins are very fine menisci of mudrock infilling the trace, with few ostracods. These burrows are found only in the ostracod-rich, horizontally laminated mudrocks, where they are common. These burrows match the characteristics of crayfish burrows in having, vertical orientation that crosses stratigraphy, and agglutinated mud margins (Hasiotis et al., 1998).

\section{Member C Paleontology \& Taphonomy}

A number of frog specimens have been recovered near the top of Member C (Fig. 2). In addition to anurans, this member preserves abundant mollusks, ostracods, and rare unidentified plant impressions. The most fossiliferous lithofacies in Member C are planar-laminated, silty limestones (packstones) and calcareous siltstones. Less common in the member are trough-cross- 
342 bedded and ripple-marked litharenitic sandstones, trough-cross-bedded polymict conglomerates,

343 and rare oncolitic limestones, but to date these lithofacies have not produced any vertebrate

344 fossils.

$345 \quad$ Member C differs from Member B in that invertebrate remains are found within the same

346 lithofacies and with similar preservation as the vertebrates. Two taphonomic modes are

347 observed. Taphonomic Mode 4 consists of frogs, ostracods, and bivalves occurring together

348 within horizontally laminated, calcareous siltstones (cf. SCNHM VAF 4, Fig. 11a) and in

349 laminated to finely bedded silty ostracod packstones (cf. CM 89263, Fig. 11b). Ostracods in

350 Member C do not show signs of "swarming" (in contrast to Member B), and bivalves are fully

351 articulated, unlike those in the tempestite beds of Taphonomic Mode 3 in Member B. Ostracod

352 density seems to be rather uniform, whereas bivalve density is variable. The depositional

353 environment of Taphonomic Mode 4 is interpreted to be a lacustrine fan-delta (Druschke, 2008).

354 As in the case of Member B, the ostracod and bivalve taxa indicate an alkaline pH (Good, 1987;

355 Swain, 1987). Similar to Member B, frogs from this taphonomic mode are nearly complete and

356 in life position. This suggests that the frogs were subjected to minimal or no dessication (Smith,

357 1986), transport, or scavenging. The well preserved "life posture" of these frogs is also similar to

358 taphonomic processes occurring in Member B in requiring the body to settle to the bottom within

359 a few days to three weeks of death (Dodson, 1973; Iniesto et al., 2017), and the low water

360 temperature retarding bloating and disarticulation (Elder, 1985). Given that Member C is

361 interpreted to be a deltaic environment, the sedimentary laminae are not varves. A low-energy

362 environment is supported by the presence of articulated bivalves (Good, 1987). At least three

363 horizons, and likely more as yet unidentified, of this taphonomic mode with multiple-individuals

364 per bed suggests a recurring mortality event. There are no frog larval remains preserved in these 
365 beds, only post-metamorphic individuals of varying size. The similar preservational state and

366 presence of more than one individual per bedding plane is further evidence that these were

367 indeed discrete mortality events rather than attrition, in contrast to Member B Taphonomic

368 Modes 1 and 2.

369 The accumulation mechanism may be a result of either biotic or abiotic factors. If these

370 were terrestrial frogs, then the accumulation could be attributed to the congregation of frogs in

371 the lake to breed. Abiotic accumulation mechanisms could have included carcasses being blown

372 by lake fetch (i.e., Henrici and Fiorillo, 1993), low-density turbidity currents (Smith, 1986), or

373 perhaps some other low energy current. Whether by biotic or abiotic factors, these individuals

374 died in discrete events, were accumulated via biotic or abiotic factors, and sank to the bottom of 375 the lake.

376 Taphonomic Mode 5 is odd, in that frogs are the only preserved organisms and they are

377 completely disarticulated; invertebrates are completely lacking (cf. SCNHM VAF 11, Fig. 12).

378 Given that none of the frog elements display evidence of subaerial weathering, we suggest that

379 they were not exposed to air and light for any significant amount of time. Furthermore, no signs

380 of abrasion are present, which supports the interpretation of minimal transport distance. The

381 bones show no strongly preferred orientation. The presence of bones of a wide array of sizes in a

382 poorly-sorted matrix supports the conclusion that these elements were deposited in a single

383 depositional event. An interesting observation is that many elements occur in a bone-to-bone

384 contact relationship, indicating that the bones were denuded of flesh prior to burial. There are no

385 observable articulations or close associations, suggesting that the animals were disarticulated

386 when they became entrained within the depositional environment. These bones likely represent

387 the reworked remains of individuals found at the base of these discrete bone-bearing beds of 
388 Taphonomic Mode 4 for Member C. There does not appear to be any winnowing of elements as

389 per Voorhies (1969) groups. These bonebed horizons can be traced laterally over a kilometer.

390 Actualistic studies of frog and toad carcasses in pond water show that frogs can begin

391 disarticulating within 21 days, but they remain mostly articulated for up to 45 days (Dodson,

392 1973). Therefore the depositional event was not likely the cause of death; the frogs were already

393 dead and in the catchment before the event. There are no tell-tale signs of scavenging of

394 elements, such as green-stick fractures or tooth marks. Mass die-offs of anurans are known to

395 occur today (e.g., Lips, 1999; Rachowicz et al., 2006) and have been invoked in other prehistoric

396 instances (Henrici \& Fiorillo, 1993). Given the wide range of element sizes and random

397 orientation of elements, we interpret this taphonomic mode to be a non-selective event

398 assemblage. Henrici \& Fiorillo (1993) proposed lake fetch as one of several hypotheses for the

399 dense accumulation of frogs in a nearshore environment. We hypothesize that in this instance the

400 frogs were already dead and decomposing, and that the concentrating mechanism was also

401 sedimentary. In this case we cannot conclusively determine the depositional mechanism for the

402 jumbled assemblage, perhaps a sediment gravity flow (as per Smith, 1986), or a tempestite bed

403 similar to those of Member B.

404 Discussion

405 Results of the taphonomic analysis complements previous studies (Coney and Harms, 406 1984; Jones et al., 1998; Dilek and Moores, 1999; DeCelles, 2004; Snell et al., 2014), which

407 indicate that the Sheep Pass Formation was deposited in a high-elevation setting. The

408 preservational modes of the fossil frogs indicates that cool water temperatures prevented them

409 from bloating and floating before settling onto the lake bottom. This seems surprising as periods

410 of extreme global warming occurred during the early Paleogene (Zachos et al., 2001), which 
411 should have resulted in water temperatures warm enough to cause carcasses to bloat and float.

412 High elevation of the Sheep Pass Formation lake system is the most likely explanation for cool

413 water temperatures. Further support for the Sheep Pass basin being a cool-water lacustrine

414 system is found in Good (1987), who observed that, although palynological data from the Rocky

415 Mountain region indicates a tropical to subtropical climate during the time of Sheep Pass

416 Formation deposition, a modern analog for the Sheep Pass Formation molluscan association of

417 Valvata, Hydrobia, Sphaeriridae in a tropical to subtropical realm does not exist. It was when

418 Good (1987) looked to literature on more temperate, cooler water lakes inOntario, Minnesota,

419 and Maine that he found modern analogs to the Sheep Pass Formation molluscan fauna.

420

Although the frogs of taphonomic modes 1-4, are mostly complete they show no signs of

421 soft-tissue preservation, in contrast to other examples of frog-bearing lagerstatten. Although soft-

422 tissue can be conserved for a number of years via microbial mat action (Iniesto et al., 2017),

423 geological preservation requires subsequent sedimentary deposition. Soft-tissue preservation

424 through geologic time can be mediated by anoxic conditions (McNamara et al., 2012). In the

425 Sheep Pass Formation Taphonomic Mode 1 microbial mats likely helped to initially hold

426 carcasses together, but through post-burial diagenesis any soft-tissue impressions or residues

427 were probably lost. Post-burial diagenetic processes observed in Sheep Pass Formation rocks

428 include petrogenesis and dolomitization; these chemical processes likely did not facilitate the 429 preservation of soft-tissue post-deposition.

430 A puzzling aspect of the paleontology of the type section of the Sheep Pass Formation is

431 that no identifiable remains of any vertebrates other than frogs, with the exception of the partial

432 mammal jaw, have been found, including aquatic and semi-aquatic groups such as fish, turtles,

433 crocodilians, or waterfowl. The invertebrate fauna is considerably more diverse. One locality 
434 within the Sheep Pass Formation at Elderberry Canyon, which lies north of the type section, does

435 produce a large and varied fauna of frogs, reptiles, birds and at least 30 different types of

436 mammals (Emry \& Korth, 1989; Emry, 1990). The mammalian fauna indicates an early

437 Bridgerian age (Eocene, ca. 50-46 Ma), which is younger than the frog bearing strata at the type 438 section.

\section{Conclusions}

The Sheep Pass Formation type section, spanning the Maastrichtian to the Eocene, represents a highland, cool water, alkaline, lacustrine setting on the Nevadaplano of east-central

442 Nevada. This section preserves an abundant invertebrate fauna of gastropods, bivalves, and 443 crustaceans. It also preserves exceptionally abundant, well preserved, nearly complete, semi444 articulated, and close associations of elements of numerous frog skeletons of the species 445 Eorubeta nevadensis. The majority of frog carcasses were preserved in an environment 446 conducive to rapid settling to the lake bed without going through the bloat-and-float process.

447 Accumulation processes differ between the two members in that frogs found in Member B are a 448 result of attritional processes, whereas those in Member $\mathrm{C}$ were subjected to punctuated 449 mortality events. Multiple horizons in Member C that preserve nearly complete frogs are 450 interpreted to have been discrete mortality events. These taphonomic modes (Table 1) should be 451 useful in formulating a model of other high-elevation biotas and the preservation of biological 452 remains into the rock record.

453 454

\section{Acknowledgements}

We thank all those who helped with lab and field aspects of this project: Ty-Lor Birthisel, George Bromm, Tina Campbell, Frankie and Bob Jackson, Tom Madsen, and Pat McShea. We also thank Carrie Druschke, Becky Hall, Gene Hattori, Kristin Hilton, Jim Schmitt, Michael Wells, and our children for their support. Finally we thank the reviewers Miguel Iniesto, Dave 
458 Varricchio, an anonymous reviewer, and editor of this manuscript Fabien Knoll, as well as the 459 reviewers of a previous version of this paper.

\section{References}

461 AHDYAR, L., 2011, Molecular organic geochemistry of the oil and source rocks in Railroad 462 Valley, eastern Great Basin, Nevada, United States: Unpublished dissertation UNLV, Las $463 \quad$ Vegas, Nevada 972p.

464 ARMSTRONG, R.L., and WARD, P., 1991, Evolving geographic patterns of Cenozoic magmatism 465 in the North American Cordillera: The temporal and spatial association of magmatism and metamorphic core complexes: Journal of Geophysical Research, v. 96 (B8), p. 13.

467

468

469

470

471

472

473

474

475

476

477

478

479

BEHRENSMEYER, A.K., 1978, Taphonomic and ecologic information from bone weathering: Paleobiology, v. 4, p. 150-162.

CONEY, P.J., and HARMS, T.J., 1984, Cordilleran metamorphic core complexes: Cenozoic extensional relics of Mesozoic compression: Geology, v. 12, p. 550-554.

DeCelles, P.G., 2004, Late Jurassic to Eocene evolution of the Cordilleran thrust belt and foreland basin system, western U.S.: American Journal of Science, v. 304, p. 105-168.

DileK, Y., and MoORES, E.M., 1999, A Tibetan model for the early Tertiary western United States: Journal of the Geological Society [London], v. 156, p. 929-941.

DoDsOn, P., 1973, The significance of small bones in paleoecological interpretation. Contributions to Geology: v. 12, p. 15-19.

DruschKe, P., 2008, Sedimentology and tectonic setting of the Late Cretaceous to Eocene Sheep Pass Formation in the southern Egan Range, in Trexler, J.H., Jr. ed., 2008 Field Trip Guidebook, Nevada Petroleum Society, Reno, Nevada, 41 p. 
480 Druschke P., Hanson, A.D., and Wells, M.L., 2009a, Structural, stratigraphic, and

481

482

483

484

485

486

487

488

489

490

491

492

493

494

495

496

497

498

499

500

501 geochronologic evidence for extension predating Paleogene volcanism in the Sevier hinterland, east-central Nevada: International Geology Review, v. 51, p. 743-755.

Druschke, P.A., Hanson, A.D., Wells, M.L., Rasbury, T., Stockli, D.F., and Gehrels, G., 2009b, Synconvergent surface-breaking normal faults of Late Cretaceous age within the Sevier hinterland, east-central Nevada: Geology, v. 37, p. 447-450.

DruschKe, P.D., Hanson, A.D., Wells, M.L., Gehrels, G.E., and Stockli, D., 2011, Paleogeographic isolation of the Cretaceous to Eocene Sevier hinterland, east-central Nevada: Insights from U-Pb and (U-Th)/He detrital zircon ages of hinterland strata: GSA Bulletin, v. 123, p. 1141-1160.

DupraZ, C., Reid, R.P., Braissant, O., Decho, A.W., Norman, R.S., and Visscher, P.T., 2009, Processes of carbonate precipitation in modern microbial mats: Earth-Science Reviews, v. 96, p. 141-162.

Eberth, D.A., Rogers, R.R., and Fiorillo, A.R., 2007, A practical approach to the study of bonebeds, in Rogers, R.R., Eberth, D.A., Fiorillo, A.R., eds., Bonebeds: Genesis, analysis, and paleobiological significance, University of Chicago Press, Chicago, USA, pp. 265-332.

ELDER, R.L., 1985, Principles of aquatic taphonomy with examples from the fossil record (biostratinomy, lake sedimentation, paleolimnology, paleoichthyology, vertebrate paleontology): Unpublished Ph.D dissertation, University of Michigan, Ann Arbor, 351p.

ELDER, R.L., and SMITH, G.R., 1984, Fish taphonomy and paleoecology: Geobios, v. 17, p. 287291. 
502 EMRY, R.J., 1990, Mammals of the Bridgerian (middle Eocene) Elderberry Canyon Local Fauna 503 of eastern Nevada, in Brown, T.M., and Rose, K.D., eds., Dawn of the age of mammals 504 in the northern part of the Rocky Mountain interior, North America: Geological Society 505 of America Special Paper, v. 243, p. 187-210.

506 EMRY, R.J., and KORTH, W.W., 1989, Rodents of the Bridgerian (Middle Eocene) Elderberry 507 Canyon local fauna of eastern Nevada: Smithsonian Contributions to Paleobiology v. 67, $508 \quad 14 \mathrm{p}$.

509 FergusON, D.K., 1985, The origin of leaf-assemblages-new light on an old problem: Review of $510 \quad$ Palaeobotany and Palynology, v. 46, p. 117-188.

511 FetzNER, J.W., 2002, Crayfish Biology, http://crayfish.byu.edu/Biology.aspx, College of Life $512 \quad$ Sciences, Brigham Young University, checked March 2012.

513 FouCH, T.D., 1979, Character and paleogeographic distribution of Upper Cretaceous (?) and 514 Paleogene nonmarine sedimentary rocks in east-central Nevada, Armentrout, J.M., Cole, 515 M.R., and Terbest, H., eds., Cenozoic paleogeography of the western United States: Pacific Coast Paleogeographic Symposium 3, Pacific Section SEPM, p. 97-111.

517 Gans, P.B., Seedorff, E., Fahey, P.L., Hasler, R.W., Maher, D.J., Jeanne, R.A., and 518 SHAVER, S.A., 2001, Rapid Eocene extension in the Robinson district, White Pine County, Nevada: Constraints from 40Ar/39Ar dating: Geology, v. 29, p. 475-478

GooD, S.C., 1987, Mollusc-based interpretations of lacustrine paleoenvironments of the Sheep Pass Formation (Latest Cretaceous to Eocene) of east central Nevada: Palaios, v. 2, p. 467-478. 
523 Gutierrez-Yurrita, P.J., Sancho, G., Bravo, M.A., and Montes, C., 1998, Diet of the red 524 swamp crayfish Procambarus clarkia in natural ecosystems of the Nonana National Park 525

526

527 528 529 530

531

532

533

534

535

536

537

538

539

540

541

542

543

544 temporary fresh-water marsh (Spain): Journal of Crustacean Biology, v. 18, p. 120-127.

HASiOtis, S.T., KiRKLAND, J.I., and CALLison, G., 1998, Crayfish fossils and burrows from the Upper Jurassic Morrison Formation of western Colorado: Modern Geology, v. 22, p. 481491.

HeCHT, M.K., 1960, A new frog from an Eocene oil-well core in Nevada: American Museum Novitates, v. 2006, p. 1-14.

Henrici, A.C., Drushke, P., Hilton, R.P., And Bonde, J.W., 2018, Redescription and phylogenetic reassessment of the enigmatic anuran Eorubeta nevadensis (Amphibia) based on new specimens from the ?latest Cretaceous-Paleocene beds of the Sheep Pass Formation, Nevada: Journal of Vertebrate Paleontology, v. 38, p. 1-17.

Henrici, A.C., and Fiorillo, A.R., 1993, Catastrophic death assemblage of Chelomophrynus bayi (Anura, Rhinophrynidae) from the Middle Eocene Wagon Bed Formation of Central Wyoming: Journal of Paleontology, v. 67, p. 1016-1026.

HiCKEY, L.J., 1973, Classification of dicotyledonous leaves: American Journal of Botany, v. 60, p. 17-33.

Iniesto, M., Villalba, I., Buscalioni, A.D., Guerrero, M.C., and Lopez-Archilla, A.I., 2017, The effect of microbial mats in the deca of anurans with implication for understanding the taphonomic processes in the fossil record, Scientific Reports, v. 7: 45160.

JAMES, N.P., 1977, Facies models 8. Shallowing-upward sequences in carbonates, Geoscience Canada, v. 4, p. 126-136. 
545 Jones, C.H., SONDER, L.J., and UnRUH, J.R., 1998, Lithospheric gravitational potential energy

546

547

548

549

550

551

552

553

554

555

556

557

558

559

560

561

562

563

564

565 and past orogenesis: Implications for conditions of initial Basin and Range and Laramide deformation: Geology, v. 26, p. 639-642.

KellogG, H.E., 1964, Cenozoic stratigraphy and structure of southern Egan Range, Nevada: Geological Society of America Bulletin, v. 75, p. 949-968.

LEBRON, I. and SUAREZ, D.L., 1996, Calcite nucleation and precipitation kinetics as affected by dissolved organic matter at $25^{\circ} \mathrm{C}$ and $\mathrm{pH}>7.5$ : Geochmica et Cosmochimica Acta, v. 60, p. $2765-2776$.

LIPS, K.R., 1999, Mass mortality and population declines of anurans at an upland site in western Panama: Conservation Biology, v. 13, p. 117-125.

McNamara, M.E., Orr, P.J., Alcala, L., Anadon, P., and Penalver, E., 2012, What controls the taphonomy of exceptionally preserved taxa-environment or biology? A case study using frogs from the Miocene Libros konservat-lagerstatte (Teruel, Spain), PALAIOS, v. 27, p. 63-77.

Rachowicz, L.J., Knapp, R.A., Morgan, J.A.T., Stice, M.J., VRedenburG, V.T., Parker, J.M., and BRIGGS, C.J., 2006, Emerging infectious disease as a proximate cause of amphibian mass mortality: Ecology, v. 87, p. 1671-1683.

ShIPMAN, P.G., 1981, Life history of a fossil: an introduction to taphonomy and paleoecology: Harvard University Press, Cambridge, MA, USA, 222 p.

SMITH, R.M.H., 1986, Sedimentation and palaeoenvironments of Late Cretaceous crater-lake deposits in Bushmanland, South Africa: Sedimentology, v. 33, p. 369-386. 
566 Snell, K.E., Koch, P.L., DruschKe, P., Foreman, B.Z., and Eiler, J.M., 2014, High elevation

567 of the 'Nevadaplano' during the Late Cretaceous: Earth and Planetary Science Letters, v. $568 \quad 386$, p. $52-63$.

569 Swain, F.M., 1987, Late Cretaceous? And Paleogene freshwater Ostracoda from central and 570 eastern Nevada: Review Espanola de Micropaleontologia, v. 17, p. 181-227.

571 TIDWELL, W.D., 1998, Common fossil plants of western North America: Smithsonian Institution 572 Press, Washington D.C., 299 p.

573 VOORHIES, M.R., 1969, Taphonomy and population dynamics of an early Pliocene vertebrate 574 fauna, Knox County, Nebraska: Contributions to geology, special paper 1, University of $575 \quad$ Wyoming, Laramie, 69 p.

576 Wilkinson, I.P., Wilby, P.R., Williams, M., Siveter, D.J., and VANnieR, J., 2007, Ostracod 577 carnivory through time, in Elewa, A.M.T., ed., Predation in organisms: a distinct

578 phenomenon: Springer-Verlag, Heidelberg, p. 39-57.

579 WINFREY Jr., W.M., 1958, Stratigraphy, correlation, and oil potential of the Sheep Pass 580 Formation, east-central Nevada: American Association of Petroleum Geologists, Rocky 581 Mountain Section of Geological Records, p. 77-82.

582 WINFREY Jr., W.M., 1960, Stratigraphy, correlation, and oil potential of the Sheep Pass 583 Formation, east-central Nevada: Intermountain Association of Petroleum Geologists, 584 Eleventh Annual Field Conference Proceedings, p. 126-132.

Zachos, J., Pagani, M., Sloan, L., Thomas, E., and Billups, K., 2001, Trends, rhythms, and 586 aberrations in global climate 65 Ma to present: Science, v. 292, p. 686-693. 
Figure 1

Geologic Map of east-central Nevada

A geologic map of east-central Nevada. The Sheep Pass Formation type-section is denoted in the small white inset box in the south Egan Range.

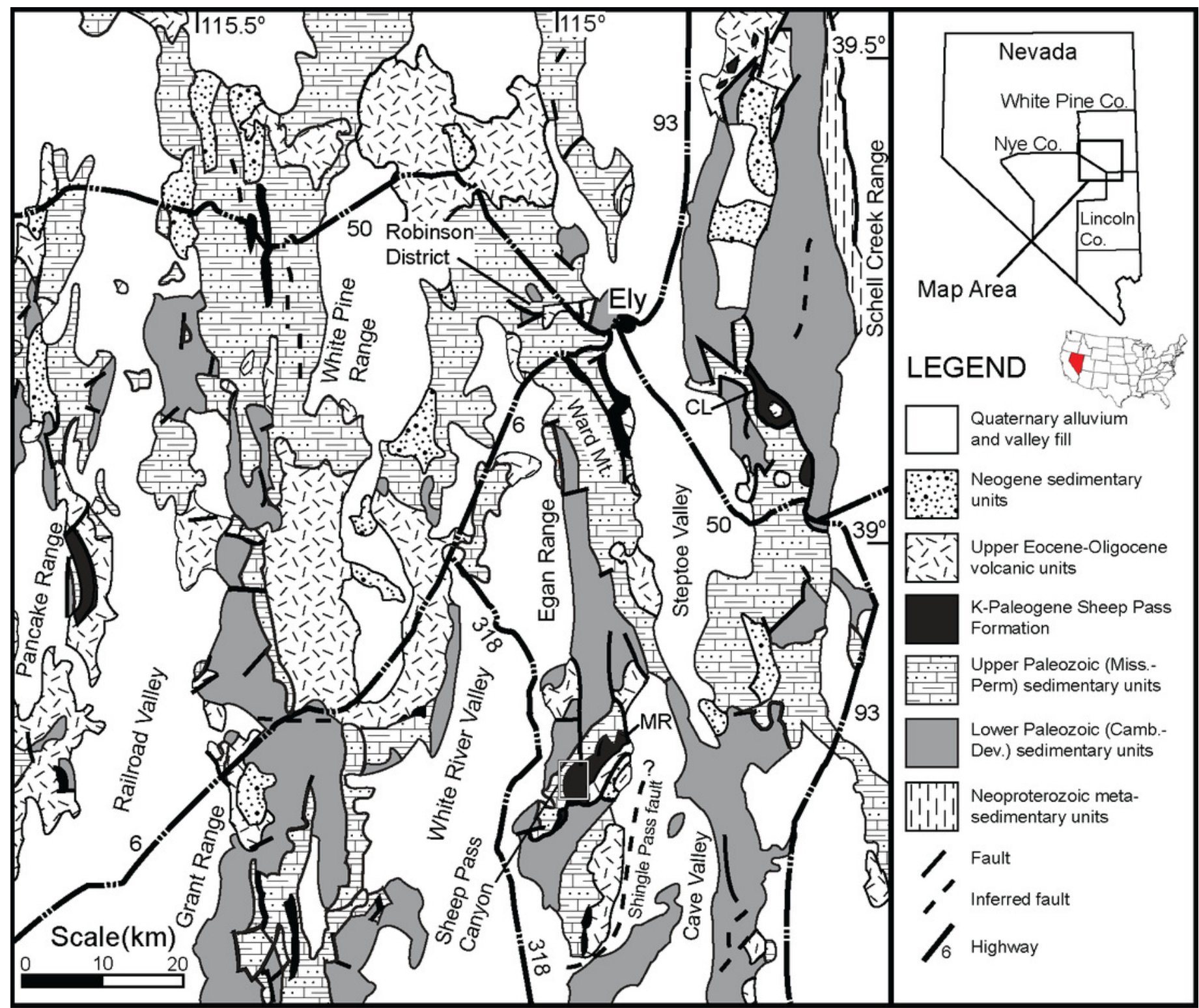


Figure 2

Stratigraphic section of the Sheep Pass Formation

Stratigraphy of the Sheep Pass Formation type section showing where absolute dates have been aquired and approximate distribution of frog fossils. Frogs are found throughout Member B, and in discrete beds at the top of Member C. 


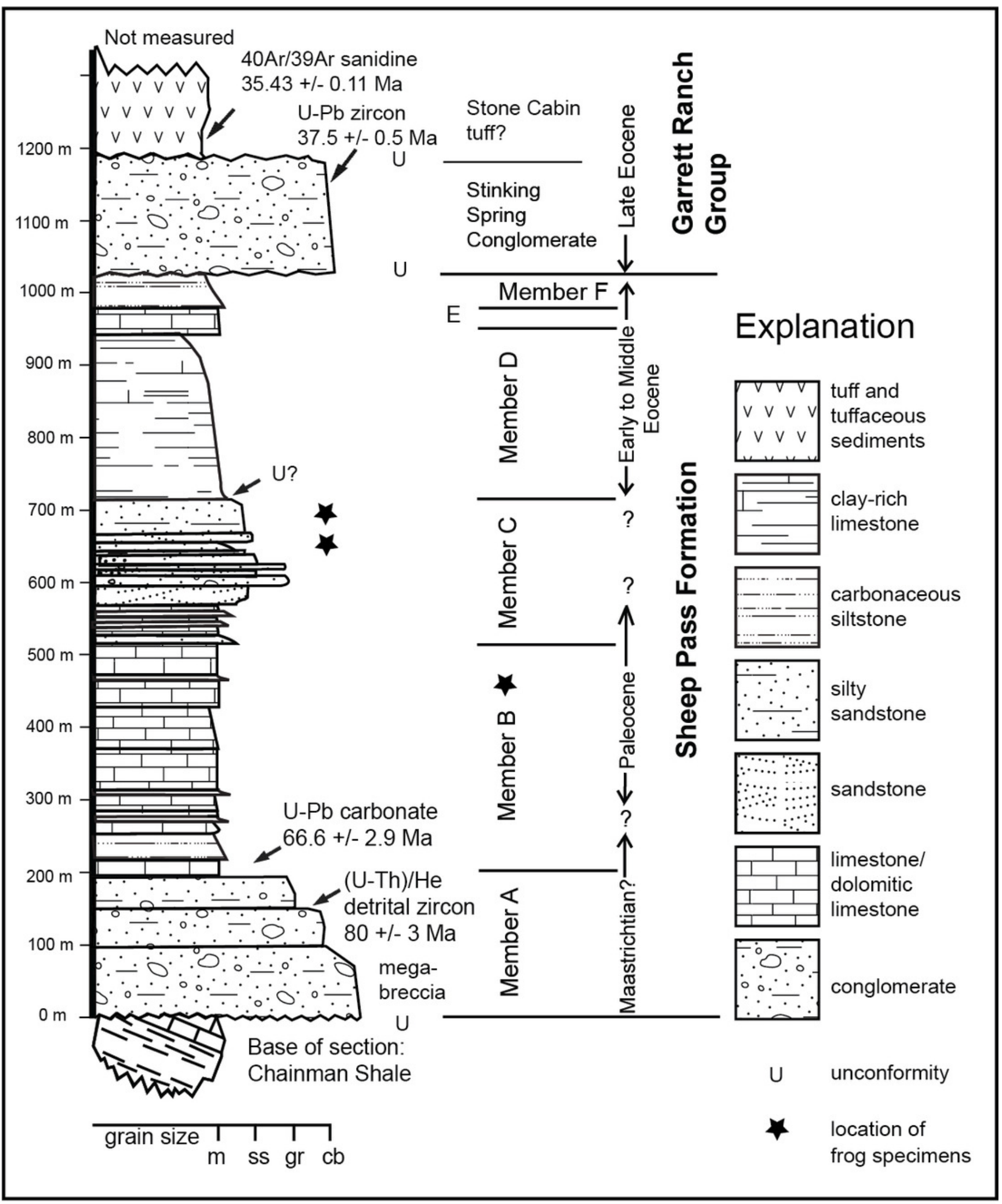


Figure 3

Representative plant fossils

Plant impressions along a fine-grained mudrock horizon from Member B.

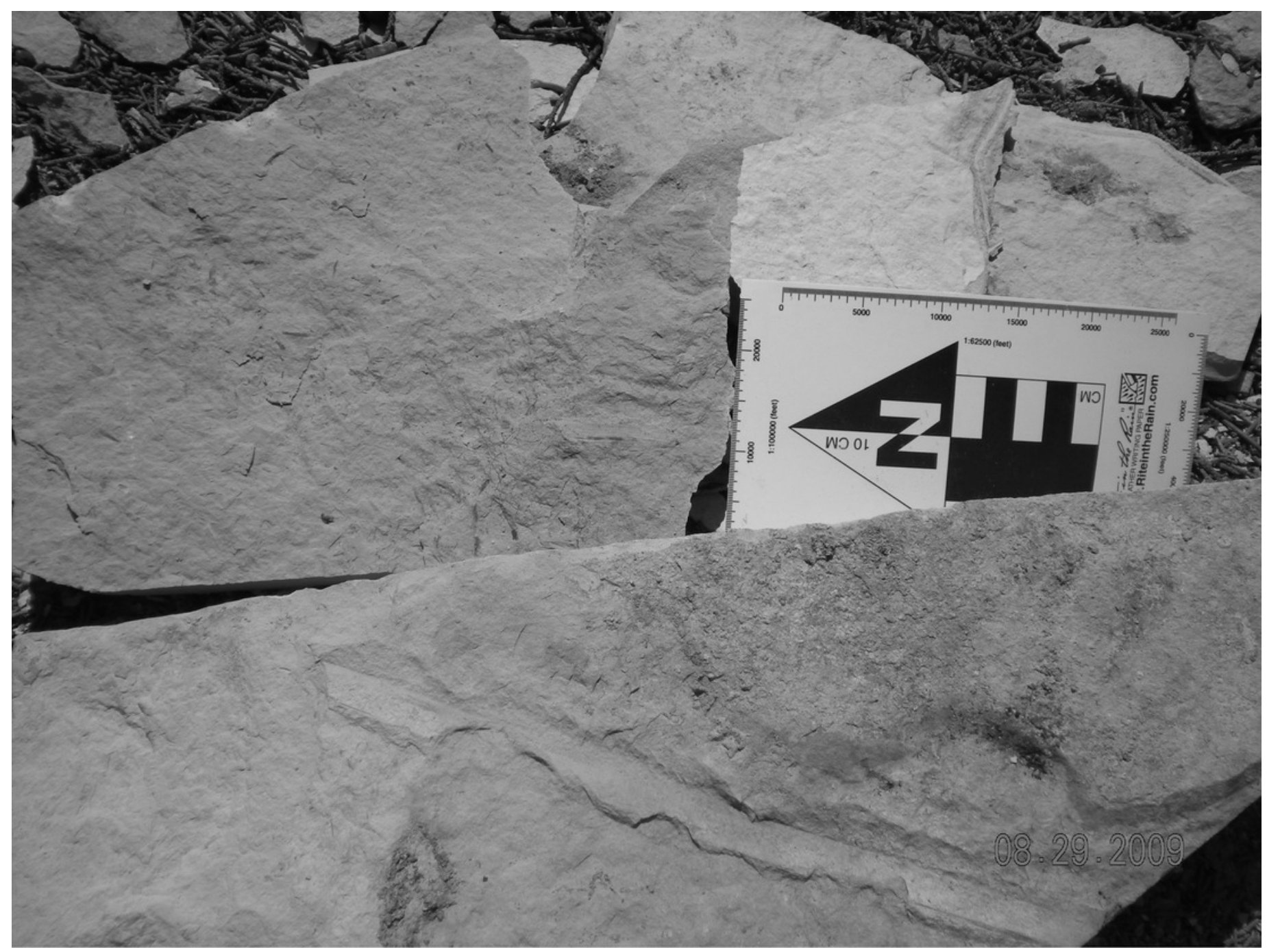


Figure 4

Eucamptodromus leaf impression in Member B

A eucamptodromus leaf impression in fine-grained facies of Member B. The line diagram illustrates the veination of the impression, showing the arcuate secondary veins. 

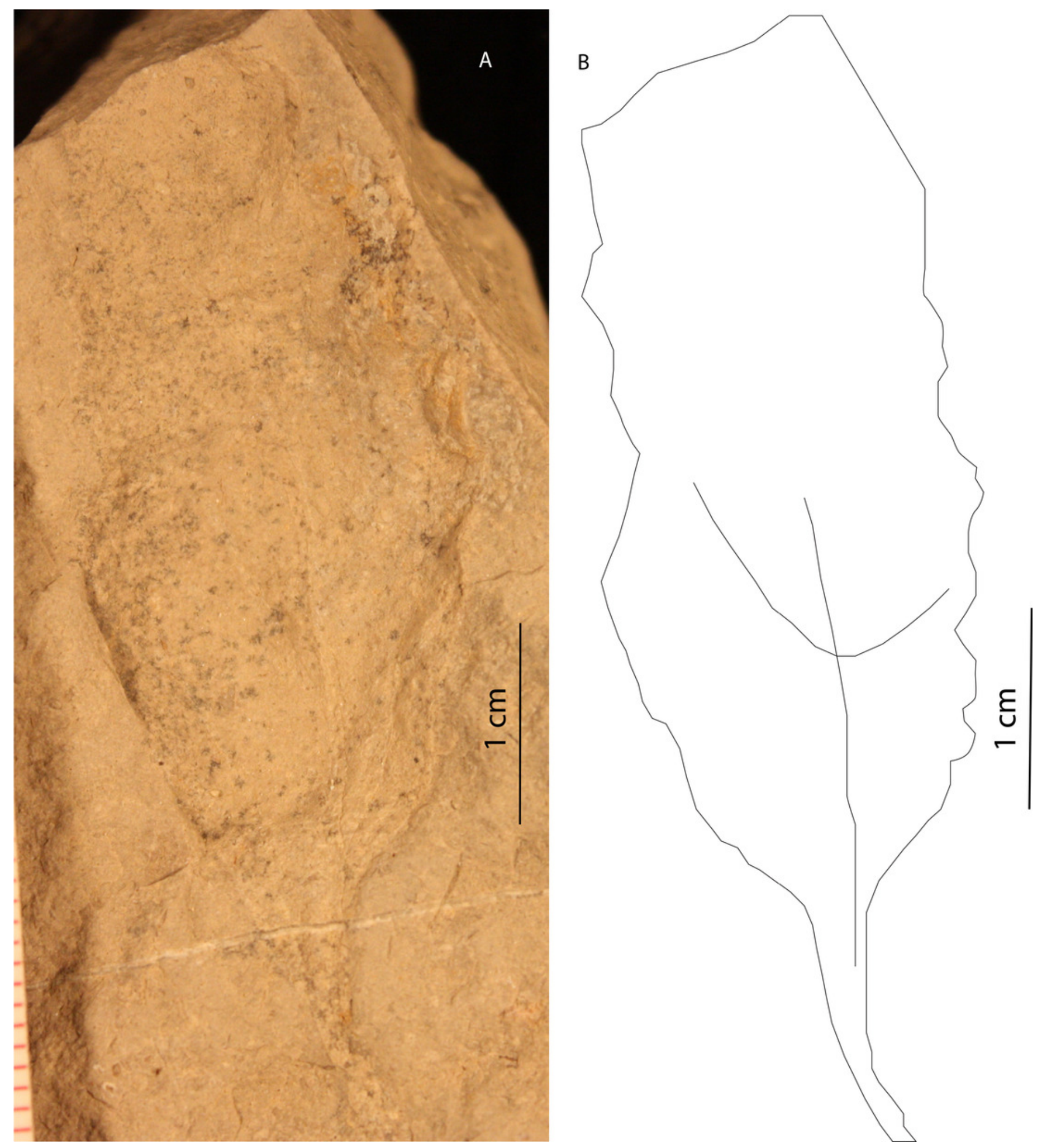
Figure 5

Decapod molted exoskeleton

A likely molted decapod exoskeleton. To the left is the telson with abdominal somites, to the right would be the cephalothorax.

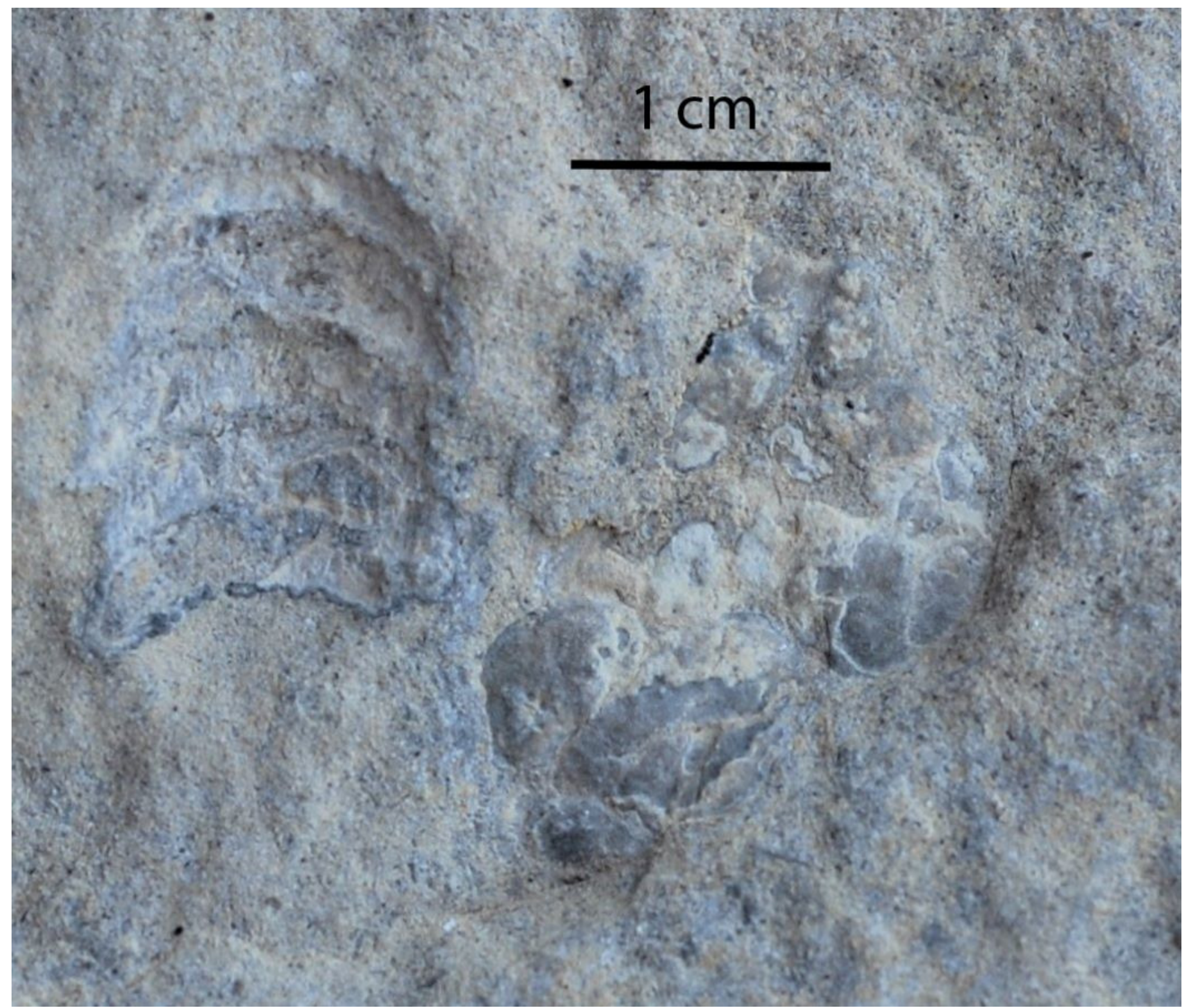




\section{Figure 6}

Ostracods in association with frog bones in Member B

The laminated mudstone facies with a disarticulated frog vertebral column. Small oval structures are ostracod carapace remains.

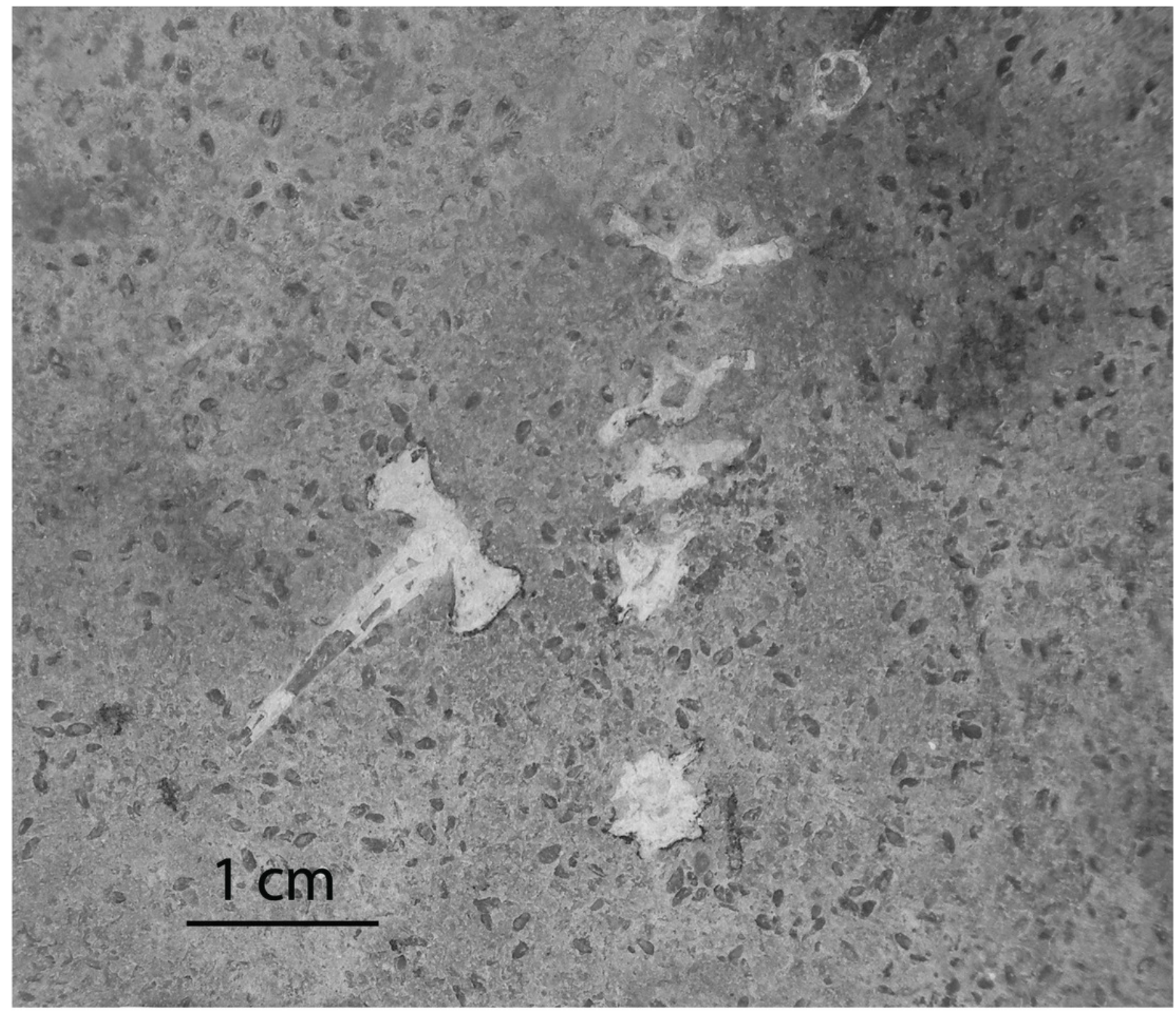


Figure 7

Taphonomic mode one of Member B

A nearly complete frog (SCNHM VAF 3), in life position, preserved in the crenulated limestone fabric. This setting is interpreted as microbialite facies.

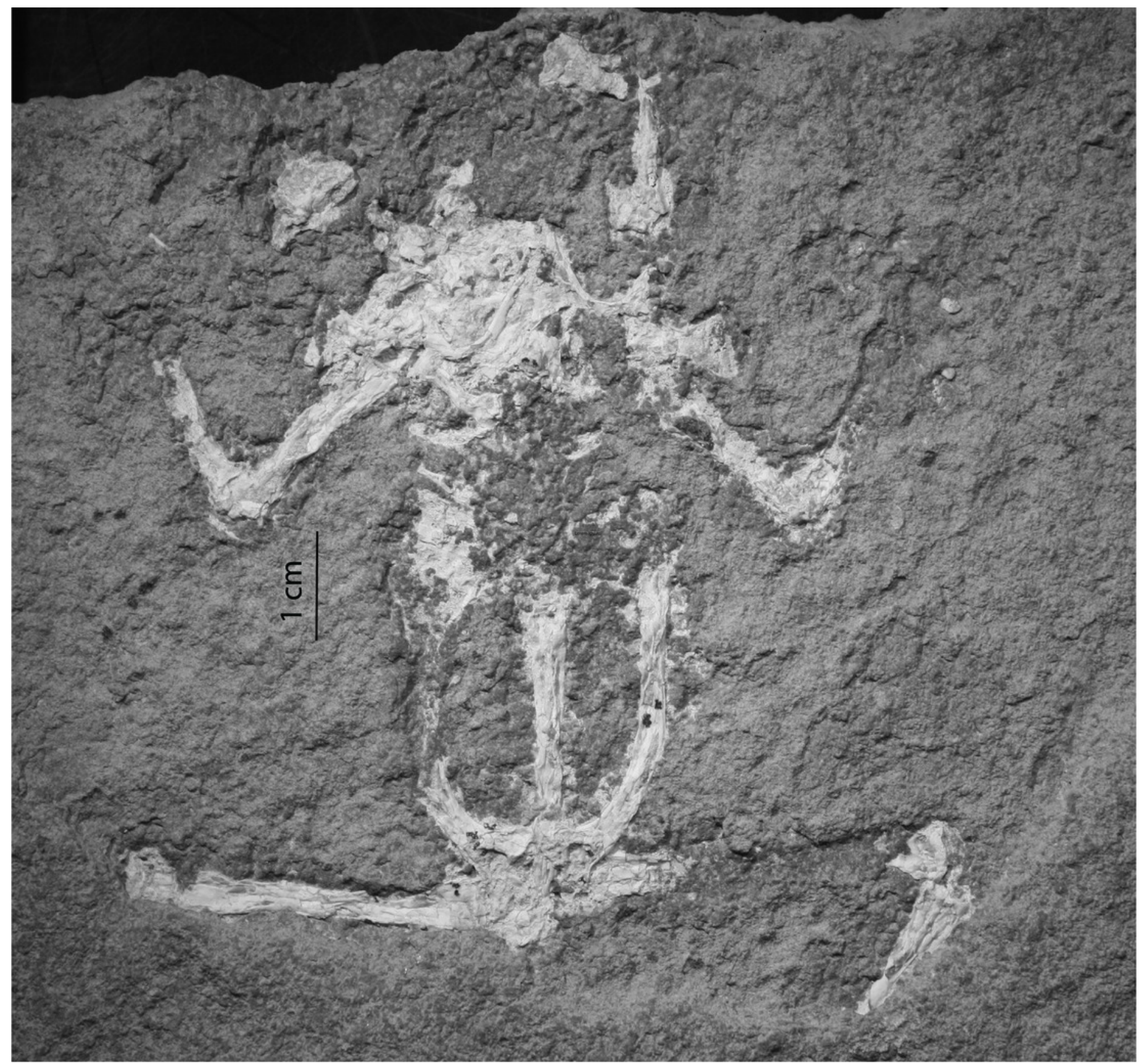


Figure 8

Taphonomic mode two of Member B

A nearly completely articulated frog (SCNHM VAF 26), with some disarticulated and associated elements. This specimen also shows ostracod swarming, with carapace to bone contact in some places. This specimen is preserved in a laminated mudstone. 


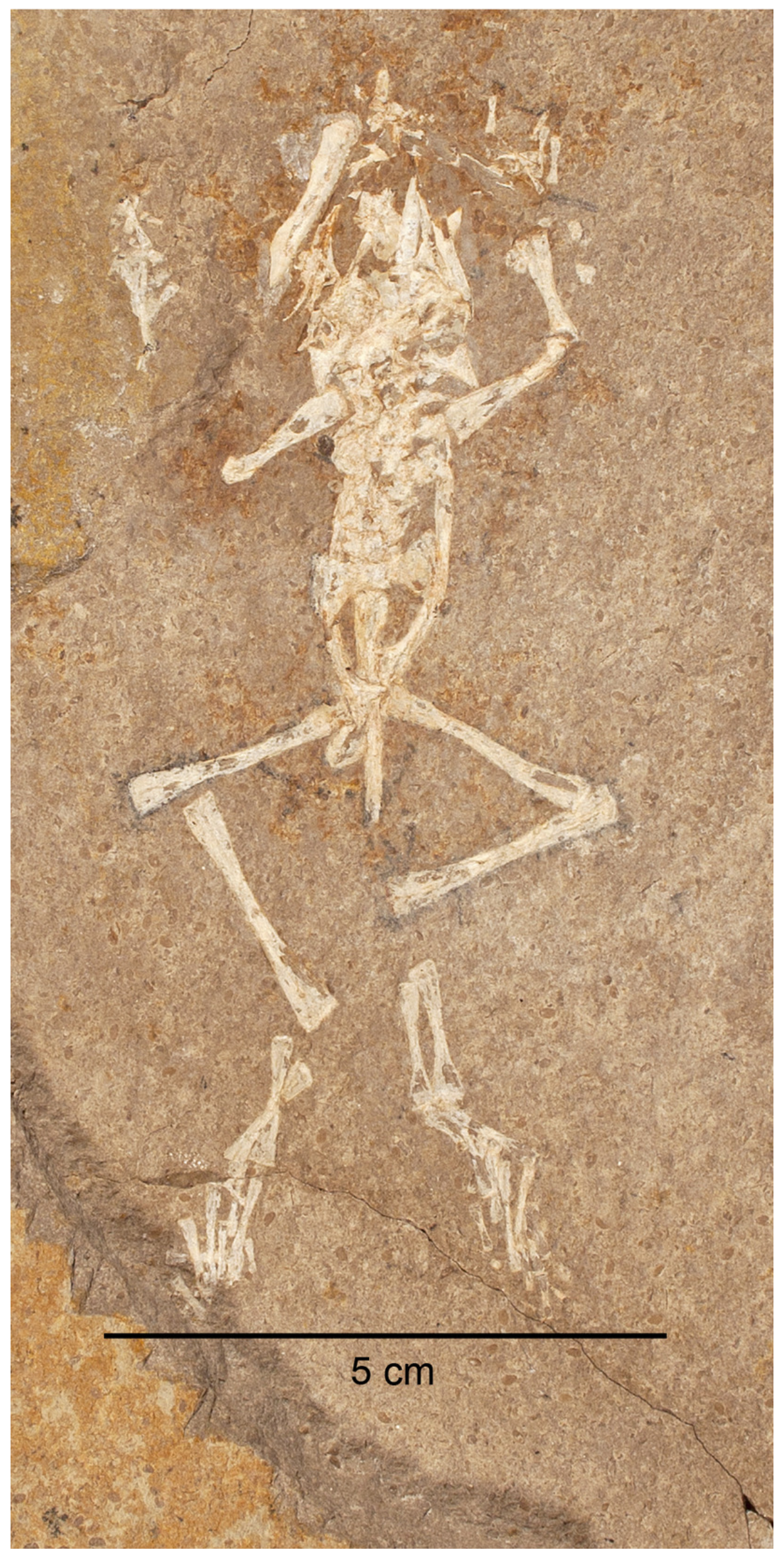

Peer) reviewing PDF | (2020:01:44927:1:2:NEW 4 May 2020) 


\section{Figure 9}

Invertebrate trace through crenulated fabric of Member B

An invertebrate trace fossil found in the crenulated, microbialite of Member B. Invertebrate activity shows that bottom waters were not anoxic or so dysoxic that invertebrate scavengers would not have had access to vertebrate remains.

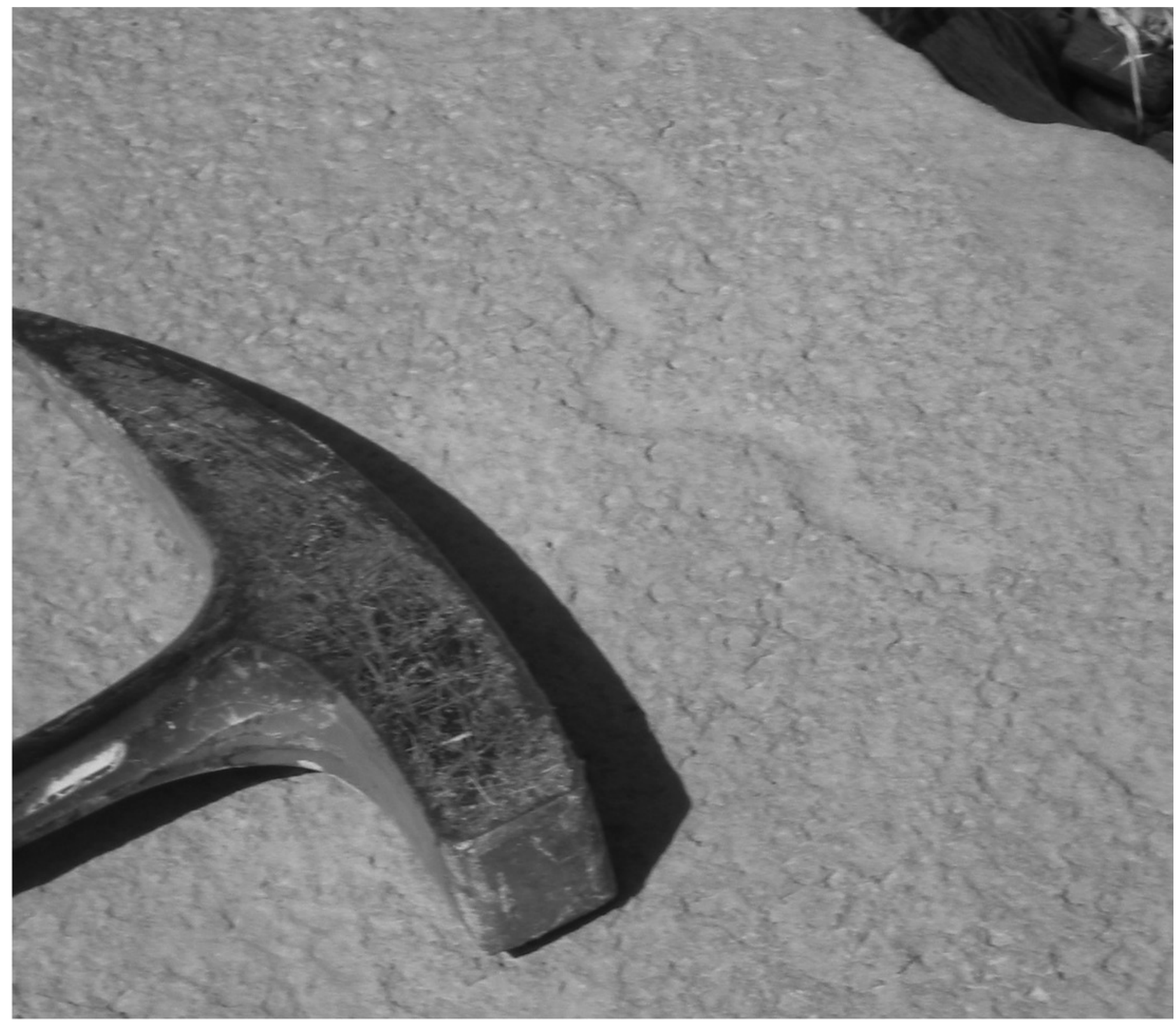




\section{Figure 10}

Sawed in half invertebrate burrow

One of the circular invertebrate traces sawed in half, showing the internal structure. Notice along the edges the darker agglutinated periphery of the burrow.

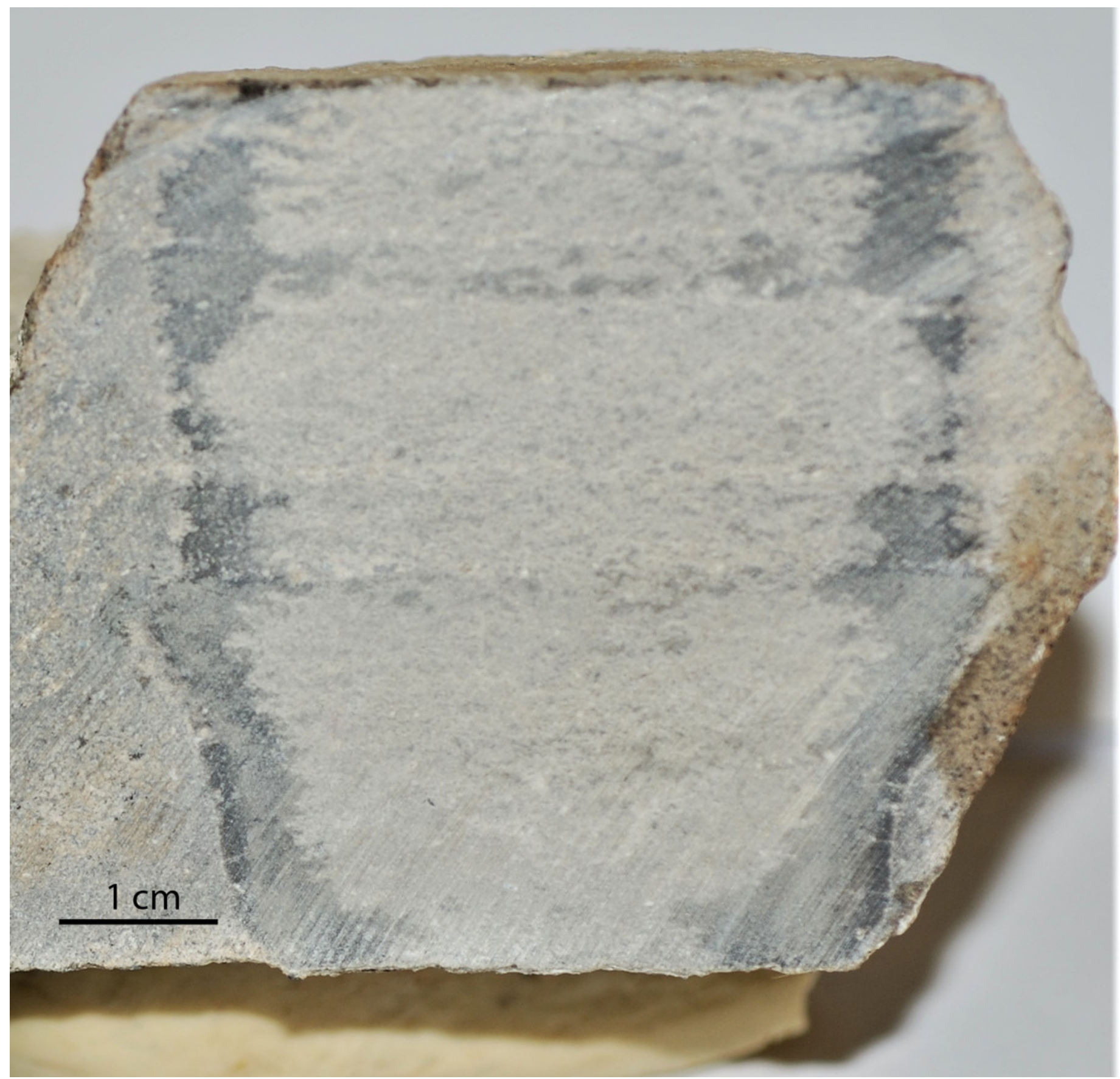




\section{Figure 11}

Taphonomic Mode Four in Member C

Taphonomic Mode Four in Member C preserves frogs, ostracods and bivalves in near life position. These frogs are preserved in silty, laminated limestones as in A (SCNHM VAF 4); or in ostracod-bivalve packstones as in B (CM 89263). The inset box in B shows a blown up view of the matrix, highlighting the packstone nature of the invertebrate remains.
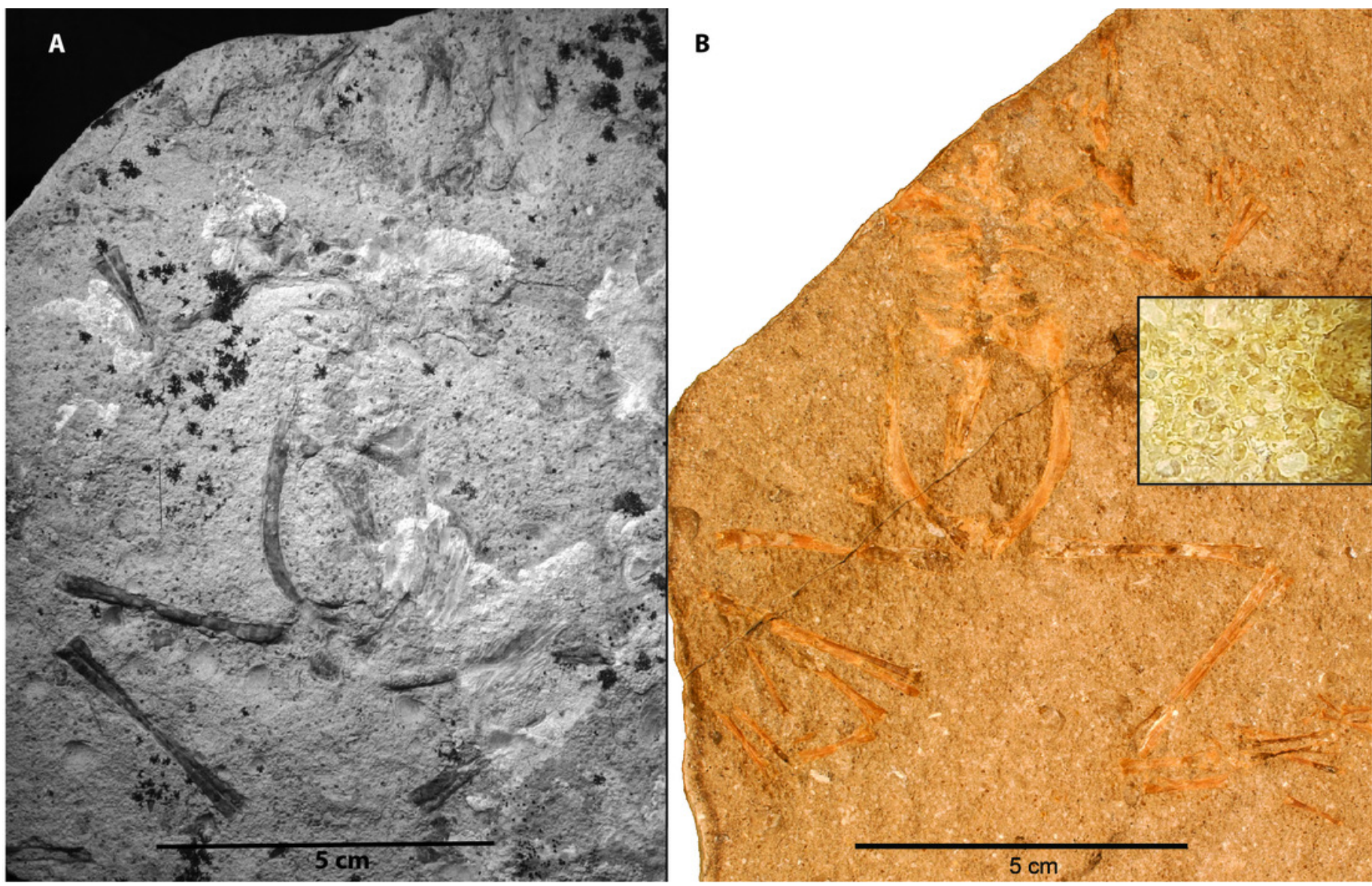


\section{Figure 12}

Taphonomic Mode Five preserved in Member C

This specimen is a sample of the frog bonebed (SCNHM VAF 11). This horizon extends for over a kilometer laterally, there is no preferred orientation of elements, and the bones are preserved in bone to bone contact in a silty-very-fine sandstone matrix.

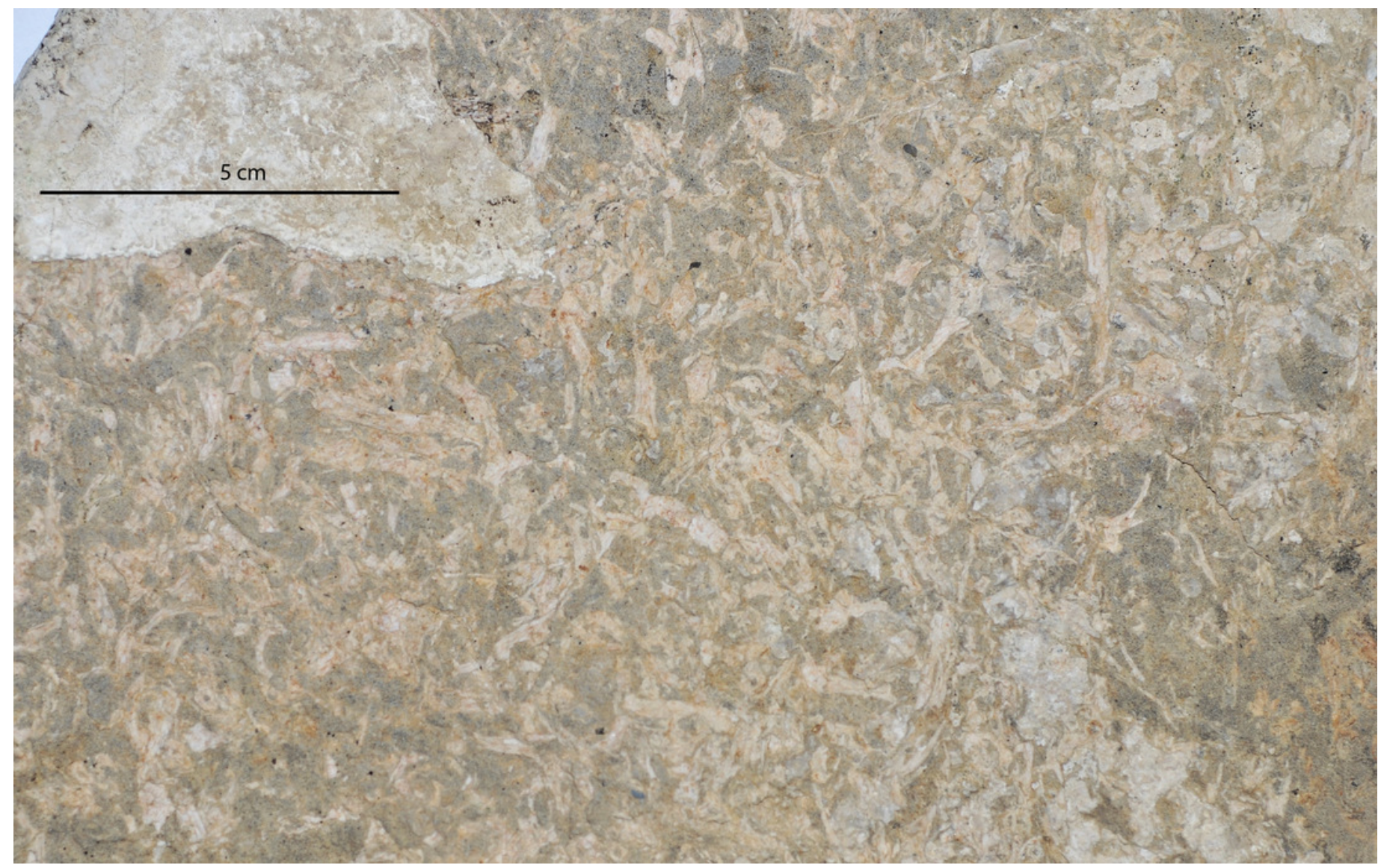




\section{Table 1 (on next page)}

Lithologies and Taphonomic Modes of Frog remains in the Sheep Pass Formation

Lithologies, depositional environments, and tahponomic modes of frog remains from Members B and C of the Sheep Pass Formation 
1 Table 1. Summary of lithofacies, fossils present, and depositional environments, with vertebrate 2 taphonomic modes.

\begin{tabular}{|c|c|c|c|}
\hline Lithofacies & Plants \& Inverts & Frogs & Depo. Environment \\
\hline $\begin{array}{l}\text { Member B } \\
\text { Dolomitic clayshale }\end{array}$ & $\begin{array}{l}\text { Plant impressions, no } \\
\text { animal body or trace } \\
\text { fossils }\end{array}$ & No frogs & $\begin{array}{l}\text { Shallow lacustrine } \\
\text { with emergent veg. }\end{array}$ \\
\hline $\begin{array}{l}\text { Crenulated-fabric, } \\
\text { irregularly- } \\
\text { laminated, } \\
\text { dolomitic } \\
\text { mudstone }\end{array}$ & $\begin{array}{l}\text { Allochthonous leaves, } \\
\text { common invertebrate } \\
\text { trace fossils }\end{array}$ & $\begin{array}{l}\text { Abundant, } \\
\text { nearly } \\
\text { complete } \\
\text { frogs }\end{array}$ & $\begin{array}{l}\text { Shallow, lacustrine, } \\
\text { microbial mats } \\
\text { Taphonomic Mode } 1\end{array}$ \\
\hline $\begin{array}{l}\text { Planar-laminated, } \\
\text { dolomitic } \\
\text { mudstone }\end{array}$ & $\begin{array}{l}\text { Abundant invertebrate } \\
\text { body and trace fossils. No } \\
\text { plants }\end{array}$ & $\begin{array}{l}\text { Abundant, } \\
\text { nearly } \\
\text { complete and } \\
\text { associated } \\
\text { frogs }\end{array}$ & $\begin{array}{l}\text { Low-energy } \\
\text { lacustrine } \\
\text { Taphonomic Mode } 2\end{array}$ \\
\hline $\begin{array}{l}\text { Irregularly bedded } \\
\text { mudstone with } \\
\text { common mud rip- } \\
\text { up clasts }\end{array}$ & $\begin{array}{l}\text { Abundant articulated and } \\
\text { disarticulated bivalves }\end{array}$ & $\begin{array}{l}\text { Isolated } \\
\text { elements }\end{array}$ & $\begin{array}{l}\text { Tempestites } \\
\text { Taphonomic Mode } 3\end{array}$ \\
\hline $\begin{array}{l}\text { Member C } \\
\text { Horizontally- } \\
\text { laminated, } \\
\text { calcareous } \\
\text { siltstones and } \\
\text { packstones }\end{array}$ & $\begin{array}{l}\text { Abundant, articulated } \\
\text { bivalves and ostracods. } \\
\text { No plants }\end{array}$ & $\begin{array}{l}\text { Common, } \\
\text { nearly } \\
\text { complete } \\
\text { frogs. }\end{array}$ & $\begin{array}{l}\text { Lacustrine delta } \\
\text { Taphonomic Mode } 4\end{array}$ \\
\hline $\begin{array}{l}\text { Massive, irregular } \\
\text { bed of varying } \\
\text { grain-size and } \\
\text { element density }\end{array}$ & No plants or inverts & $\begin{array}{l}\text { Abundant, } \\
\text { disarticulated } \\
\text { frog } \\
\text { elements }\end{array}$ & $\begin{array}{l}\text { Sediment gravity } \\
\text { flow or tempestite } \\
\text { Taphonomic Mode } 5\end{array}$ \\
\hline
\end{tabular}

